\title{
IntRoduction: Poetry of the Russian Silver Age
}

\author{
Sibelan Forrester and Martha Kelly
}

Doetry is only one of the exciting cultural achievements of the Russian fin-de-siècle, which has come to be known as the Silver Age. Along with the Ballets russes, the music of Alexander Scriabin or Igor Stravinsky, the avantgarde painting of Kazimir Malevich or Marc Chagall, and the philosophical writings of Lev Shestov or Nikolai Berdyaev, poetry is one of the era's most precious treasures. The Silver Age witnessed an unprecedented and fruitful interaction between Russian literature and the other arts, sometimes within the same person: several of the major poets were (or could have been) musicians and composers; others were painters, important literary critics, religious thinkers, scholars, or philosophers. The culture of book illustration and graphic presentation of poetry rose to new heights, from Mstislav Dobuzhinsky's gorgeous initial letters in the Acmeist journal Apollon to the Cubist-tending images in Futurist publications.

The Silver Age also saw the emergence of a much wider range of poets than earlier periods: the poets in this collection represent a striking variety of class, gender, religion, ethnicity, and sexuality. There were plenty of aristocratic writers, of course (like Count Leo Tolstoy, the moral and literary giant whose importance continued right up to his death in 1910). The aristocrats had a better education, access to foreign languages and travel, and money to self-publish when publishers weren't biting. But there were also "raznochintsy" (figures of mixed social background, like Valery Bryusov or Marina Tsvetaeva—-though in 
early Soviet literary surveys Tsvetaeva called herself, perhaps as a matter of provocative principle, a member of the nobility). Several of our poets are Jews. Even though Boris Pasternak's father Leonid had converted to Christianity, and Sofia Parnok and Osip Mandelstam themselves converted, Judaism still remained important in their writings: they were part of a generation of assimilated Jews in the Russian Empire with highly sophisticated literary knowledge, eager to shape the literary culture of the time. Several of our poets are women (you can tell by the -a that ends most Russian women's surnames). There had been prominent and successful female poets before-Karolina Pavlova (18071893), Evdokia Rostopchina (1811-1856) — but the Silver Age was the first era when Russian women writers not only became prominent, but stayed prominent. Perhaps it was the crashing disruption of the 1917 Revolution, which put Silver Age poetic achievements into a kind of deep freeze, fixing the fame of its best-known women writers in a way that had not occurred earlier in Russian literary history. Two of our poets are peasants (Sergei Esenin, fairly well known in the West, and Nikolai Klyuev, less well known), and genuine peasant speech became more of a factor in the writings of non-peasant poets even before the 1917 Revolution. Our poets often express great interest in religious variety, sometimes springing from their own backgrounds: Klyuev and Mikhail Kuzmin describe Old Believer communities; Andrei Bely, Alexander Blok, and Tsvetaeva are interested in the Khlyst ("flagellant") sect; Vyacheslav Ivanov is a specialist in Classical Antiquity, particularly drawn to Greek mystery religions not only as a literary source but also as models of behavior for his own life; Zinaida Gippius and Dmitri Merezhkovsky were prominent creators or theorists of new religious rites; and we have already mentioned Jewish voices such as those of Mandelstam or Nikolai Minsky (pseudonym of Nikolai Vilenkin, 1855-1937), whose poetic and publicistic activity still awaits scholarly treatment in English. The writer and philosopher Vasily Rozanov also engaged, imaginatively and sometimes problematically, with Judaism. Last, but far from least, the Silver Age saw both a relaxation of censorship and a growing interest in alternative theories and models of sex and gender, so it is no surprise to find in the Silver Age the first open, published writing about gay and lesbian topics (by Kuzmin, Klyuev, Parnok, and others), and intense interest in sexuality on the part of other poets, many of them bisexual in theory if not in practice. 
This quick survey of "identity politics" does not limit the area these various poets covered-on the contrary, it broadens it significantly. In some cases the Silver Age began to talk more openly and transformatively about difficult topics (sexuality, religion, the implications of gender-and of course economic and social class, always a Russian specialty) than our own society has been prepared to do until much more recently (if, indeed, it has reached that level of willingness today). In many cases, the poets combined interests or concerns that may not seem harmonious at first glance, but that add particular angles to their work-for example, Kuzmin, whose homoerotic verse and powerful religious impulse came together in a spiritualization of aesthetic values that resonates with Russian Orthodox traditions as much as it does (though differently) with Classical and Hellenistic Greek culture.

You can expect that variety in this collection, embodied in some of the most wonderful poetry in the world. The collection includes the names anyone would look for in an anthology of the period (Akhmatova, Blok, Mandelstam, Mayakovsky, Pasternak, Tsvetaeva), while also selecting some (though far, far from all!) poets who are less well-known or well-studied but nonetheless talented and fascinating, and who added to the diversity and energy of the era. These poets are valuable parts of the cultural landscape of Russia, and they are also writers who can still shake you with their raw energy and the passionate conviction of their aesthetic seeking. They are excellent pretexts to inspiration.

\section{Why Is It Called the Silver Age?}

The cultural era from about 1890 to about 1925 is known in Russia as the Silver Age because it followed the Golden Age, the era of Alexander Pushkin (1799-1837) in which Russian poetry first reached great heights of creativity, philosophical depth, and aesthetic value. (One could expect a Bronze Age any time now ...) Indeed, the Silver Age was largely oriented towards the Golden Age, and the Silver Age bestowed on the Golden Age of Russian poetry its status, confirming the installation of Alexander Pushkin as primary deity, but also giving more attention to poets such as Evgeny Baratynsky (1800-1844), Fyodor Tyutchev (1803-1873), and Mikhail Lermontov (1814-1841), whose works had been neglected in their own times. After several decades during which the Russian Realist novel was the genre of highest prestige and 
influence, the poets of the Silver Age returned to what the Golden Age had most prized, learning their craft both from Russian poetry and from earlier and contemporary foreign poetries. They also paid new attention to more recent predecessors such as Pavlova or Afanasy Fet (1820-1892), whose works had been overshadowed earlier by the prominence of the novel. Poetry was more prized in the Russian Silver Age than it had been for several decades before; Ivan Bunin (1870-1952, winner of the 1933 Nobel Prize in Literature) wrote a sizable body of poetry, and his translation of Henry Wadsworth Longfellow's The Song of Hiawatha won a Pushkin Prize in 1903. In the next generation Ilya Ehrenburg (1891-1957), whose novel The Thaw gave its title to the cultural relaxation of repression and censorship in the Soviet Union under Nikita Khrushchev, also began literary life as a poet.

Though we call the early nineteenth century the Golden Age, the name implies that it was much better than the Silver Age, and that was not the case. The scholar Simon Karlinsky has pointed out that the Golden Age had four poets who would merit top rankings from any fan of poetry, whereas "around 1910 there lived and wrote in Russia no less than nineteen poets who easily fit into the 'major-to-great' category." (Not to mention the gender homogeneity of the poets who formed the Golden Age, and the relative uniformity of their class background.) This volume gives at least a taste of the work of twenty-eight poets, plus texts from critics, memoirists, and prose writers (many of these, in fact, the very same poets) who analyzed or exemplified the spirit of the age.

The importance to these poets of Western literature (written by predecessors and contemporaries), and of West European culture in general, makes many of these poets more "relatable" for Western readers than earlier Russian writers-although Silver Age writing can nevertheless often satisfy a taste for the "exotic." Unlike Pushkin, who was never allowed to cross the borders of the Russian empire, many Silver Age poets had profound and prolonged experience in Western Europe, traveling there while reading the best literature of the past and present. Many spent a significant amount of time in the West (sometimes using honeymoons as a pretext for extended voyaging —e.g., Andrei Bely,

1 Simon Karlinsky, Marina Cvetaeva: Her Life and Art (Berkeley: University of California Press, 1966), 4. 
Marina Tsvetaeva-and other times fleeing there for political or personal reasons-e.g., Konstantin Balmont, Maria Shkapskaya), and this assumes a significant place in their writing. The poets knew and read foreign authors, translated them, and reviewed them for the press, and Silver Age journals included regular sections describing the latest publications and all kinds of cultural happenings in other countries. Like their contemporaries in ballet, music, and the visual arts, the poets participated fully in the cosmopolitan literary culture of Europe before and even during the First World War. This ability to have it both ways would change with time. After the 1917 Revolution, our poets met a variety of fates, but these came down essentially to three: death, emigration (usually to Western Europe, where they might have visited before), or remaining in the USSR.

The liveliness of the period, and the large number of people who were writing great poetry then, let things develop very quickly. Scholars have pointed out that, in these years, new books could be published so quickly (often helped by the poet's own financial contribution) that a writer could more easily move from one stage of creative development into the next. Thus, there are two generations of Symbolists (the older Symbolists born before or around 1870, and the younger born around 1880). A "crisis of Symbolism" took place in 1910, around the time when still younger poets, born in the late 1880 s and early 1890 s - and many of whom had played a role as minor Symbolists themselves - were starting to make waves. That younger generation-the Acmeists, Futurists, or the many poets outside of the schools-includes some of the world's great Modernist poets, amazingly talented creators who often faced deeply tragic fates. These are the poets that many readers in the West have heard of, and may already have read.

\section{The Schools}

Scholars and literary historians can find it useful to look into the past and impose the name of a movement on what might in fact have been a less formal group, less organized and coherent, or what began as a group of friends who met to write and discuss literature (like the Arzamas circle in Pushkin's time), with some members emerging as very important, while others are recalled as friends of the important ones. Russian writers of other eras participated in cross-cultural literary movements like Neoclassicism, Romanticism, or 
Realism, which may also look more coherent after the fact. Many poets consciously joined, organized, and belonged to groups, naming them and creating statements of purpose, manifestos, and all manner of shared enterprises. Again, the writers of the Russian Silver Age were closely connected with the rest of Europe: they had read all the Western philosophers and visited the major European cities. Anna Akhmatova, for example, met Amadeo Modigliani in Paris; Andrei Bely spent years away from Russia, and his novel Petersburg is closer to Austrian Expressionism than to anything going on in Petersburg at the time. They quickly became aware of similar groups and ideas in the European metropoles, and vice versa.

The groups did a number of important things for their members: they focused literary discussion, sometimes sponsored formal lectures by poets with a theoretical or pedagogical bent (Bely), or organized tours in which poets performed (the Futurists). After 1917, a number of these poets taught literary courses (Gumilyov) or worked as government censors (Bryusov). The groups offered a fertile mix of support and criticism, encouraging or sponsoring one another's work, inviting participation in almanacs or debates, and reviewing one another's writings for publishers or (once published) in journals. Members would travel together, or meet by chance or agreement, to perform at the famous Stray Dog basement café in St. Petersburg (Acmeists, Futurists, even some Symbolists). Literary friends and allies regularly attended literary and cultural salons in one another's homes (such as Ivanov's famous “Tower” apartment in St. Petersburg), and would visit one another's dachas or country houses (such as Blok's family estate Shakhmatovo, where the famous mystical love triangle of Bely, Blok, and Lyubov Mendeleeva formed). The Cubo-Futurists began as a group called "Hyleia," largely oriented toward the visual arts and named for the estate in Ukraine where they met, and Maximilian Voloshin's house in Koktebel', Crimea functioned as an unofficial writer's colony for many years before its status was made official in the Soviet period. Even poets who did not join a group, like Parnok or Tsvetaeva, might attend lectures by Bely or spend time at Voloshin's house.

Just as important, if not more so, were the groups' joint and competing publishing enterprises. A surprising number of important works were selfpublished, but having a journal or a publishing house made a stronger impression, helped better advance a literary program, and worked to spread the 
wealth from older, richer, or more famous poets to newer or poorer ones. Many important Silver Age poets began their careers by asking the older ones for advice, and the older generation on the whole loved to play the role of mentor. This volume offers just a few of the letters poets exchanged, seeking or offering advice and commenting on writing. Changes in the Russian censorship laws for all kinds of publications after 1905 (with its failed revolution) made a huge difference in what poets could do; the number of periodicals and other publications rose sharply for some years after the new legislation was passed. Reviewing submissions for publication, and reviewing publications once they appeared, developed poets' critical senses and sharpened their opinions on what was happening (and, what should be happening) on the Russian literary scene, and suggested what they might want to do in imitation or in contrast with their own poetry. Once the Symbolists had established a serious literary system of poetry and a lively poetry scene, there could be reactions and rebellions by others, and this is where the discourse of the Silver Age gets especially interesting. Many of the poets and critics took a very dark view of what was going on, and this negative, cautionary attitude is represented both in the poetry and in the prose works in the second section of this volume.

\section{Symbolism, Acmeism, Futurism}

SYMBOLISM was the biggest, broadest, most general, and longest-lasting literary school of the Russian Silver Age. Our selection includes relatively few of the many Symbolists, though the big names are here. The Symbolists are commonly described as forming two generations: an older one (Balmont, Bryusov, Gippius, Ivanov, Merezhkovsky, Sologub, and many others) that began to write in the early- to mid-1890s, forming the school itself and its strong decadent wing, and a second one (Bely, Blok, and others) that began to write around 1900. Literary critics used the name by analogy with the French symbolistes, though it was not fully accepted until after the end of the Silver Age: even in the mid-1920s it was often still written in quotation marks by critics or scholars, with a lower-case letter; perhaps it was the younger poets (Tsvetaeva, Khodasevich) who firmly established it as a term of definition. On the other hand, any of those poets would have agreed that symbols were essential in the quest they had undertaken. Although the Symbolists and especially the Decadents often advanced the idea of art for art's sake, they never doubted the 
importance of a writer's civic mission and, therefore, of writing publitsistika (passionately committed journalism) for various media outlets: newspapers, journals, almanacs. This kept them intimately engaged in discussion of the big cultural and political issues of the day, and it continued the Russian tradition of using literature as a venue for political debate (though their publitsistika is less widely read today than their poetry). Many Symbolist poems addressed class enmity or cultural decline à la Oswald Spengler, themes that had been important in Realism, with fresh aesthetic power.

While writers in every era are drawn to other arts and disciplines, the Symbolists (and many "nonaligned" poets of the Silver Age as well) saw particular importance in dance, music, religion, theater, and philosophy. Meanwhile the typical Modernist quest for transcendent meaning sometimes led to interest in the occult sciences, such as astrology, palmistry, or Tarot. (The title of the Symbolist journal Vesy is usually translated as The Scales, but it also means Libra, and the publishing house Skorpion means both the creature and the astrological sign Scorpio.) Theosophy stimulated interest in various Eastern religions; Bely and apparently also Voloshin were deeply interested in Anthroposophy as propagated by Rudolf Steiner; Parnok makes poetic reference to palm reading; Tsvetaeva refers to fortune telling with playing cards and to astrology; Pasternak's complex lyric poems of the early 1920s make passing reference to homeopathy and astrology. These systems of symbols-esoteric languages that naturally attracted artists who were striving to "read" earthly reality for its ultimate significance-enriched the references to Classical Antiquity (often mediated by the scholarly Ivanov, who translated and wrote about Classical tragedies) and the approaches to more modern writers from all countries. Vladimir Solovyov's poetry and religious philosophy (some samples of which are included here) helped set the tone for the period's explorations of sex, love, and beauty.

Some relatively older poets (Annensky, Kuzmin, Voloshin) formed living links between their Symbolist peers and the younger poets and new movements who emerged around and after 1910. As Symbolism matured and then approached its "crisis" after 15-20 years of writing and publishing, it also began to serve as the background for younger movements who might reject Symbolist habits, but who depended on readers' familiarity with the Symbolists to shock and impress by doing something different. 
The Symbolists themselves reacted in a variety of ways to the newer movements. It is striking, for example, that Blok thought highly of the Futurists but was irritated by the Acmeists, whose poetry one might consider closer to his. (Rather: he was irritated by the Acmeists with the exception of Akhmatova, whom almost everyone seemed to like, even when they envied her.) The Symbolists were very self-conscious as a movement, concerned with defining and developing what they stood for as well as with the meaning of various currents within the movement, and many of them strove to advance programs or beliefs about society (in their publitsistika) or about poetry (e.g., Bely's lectures and essays on poetics). The social and political atmosphere in the decades that followed the great Emancipation of 1861, familiar to readers of the great Realist novels, gave many Symbolists both the desire to define a holistic vision with programmatic writing and a sense that it was their duty to do so. At the same time, they drew on many other literary and cultural sources, from ancient Greece to Russian folk and sectarian traditions.

Another crucial contribution of Symbolism was the practice of lifecreation (in Russian, zhiznetvorchestvo), which focused on the aesthetic qualities and trajectory of the individual's biography and arc of experiences as an aesthetic work. (This is depicted from a critical angle by Vladislav Khodasevich in "The End of Renata," in Section II.) As they observed scholars and editors studying earlier generations of writers, they began to take genres such as diary writing more seriously, so that in time almost everything written in the Silver Age was composed with an eye to the eventual reader. The Symbolist poets recognized the importance not only of writing in solitude for eventual publication, but also of meeting, debating, and collaborating, as well as founding cultural and publishing enterprises. A huge variety of poets participated in these; many of them were friends with Symbolists or moved in the same circles but did not particularly think of themselves as part of the school.

Although many Symbolists did not like the name the critics had given them (whether or not they admired Charles Baudelaire and other French poets), their attitude towards the symbolic function of poetry made the name a suitable choice. As their more theoretically oriented members wrote, the point of the movement was to move towards deeper and more important layers of reality, or ab realibus ad realiora: in essence, from everyday reality to the ultimate reality. 


\section{Brief Bibliography of Scholarly Works on Russian Symbolism:}

Davidson, Pamela, ed. Russian Literature and Its Demons. New York: Berghahn Books, 2010.

Kalb, Judith E., J. Alexander Ogden, and I. G. Vishnevetsky, eds. Russian Writers of the Silver Age, 1890-1925. Dictionary of Literary Biography 295. Detroit and New York: Gale, 2004.

Green, Michael, ed. The Russian Symbolist Theatre: An Anthology of Plays and Texts. Ann Arbor: Ardis, 1986.

Grossman, Joan Delaney. Ivan Konevskoi, Wise Child of Russian Symbolism. Brighton, MA: Academic Studies Press, 2010.

Maslennikov, Oleg. The Frenzied Poets: Andrei Biely and the Russian Symbolists. New York: Greenwood Press, 1968.

McMillan, Arnold, ed. Symbolism and After: Essays on Russian Poetry in Honor of Georgette Donchin. London: Bristol Classical Press, 1992.

Morrison, Simon. Russian Opera and the Symbolist Movement. Berkeley, CA: University of California Press, 2002.

Peterson, Ronald, ed. The Russian Symbolists: An Anthology of Critical and Theoretical Writings. Ann Arbor: Ardis, 1986.

Pyman, Avril. A History of Russian Symbolism. New York: Cambridge UP, 1994. West, James. Russian Symbolism: A Study of Vyacheslav Ivanov and the Russian Symbolist Aesthetic. London: Methuen \& Co Ltd., 1970.

ACMEISM, also known as Adamism (see Parnok's skeptical review in Section II of this volume), is known today primarily because of the poets involved: Nikolai Gumilyov was the main critic and theoretical mover, while Akhmatova and Mandelstam became the most famous members of the movement. The group was strongly influenced by Innokenty Annensky (who died before the Poets' Guild was formed) and Kuzmin (himself not a member of any school), while Voloshin collaborated significantly in the journal Apollon and elsewhere. As in all the literary movements, there were interesting secondary poets among the Acmeists-we regret not being able to include more of them, such as the prolific Sergei Gorodetsky (1884-1967), or Vladimir Narbut (1888-1938). To some extent, the terms explain themselves: "Acmeist" refers to the "acme" of poetic aspiration, and "Adamist" to the freshness of newly given names in the Biblical story, as well as to the 
members' innovative attention to origins and cultural palimpsests. The name "Poets' Guild" was chosen to emphasize the down-to-earth craft of their poetry, in contrast to the sometimes vague philosophy of the Symbolists, but also to recall the medieval and Renaissance periods, in which they were interested. The Acmeists were organized in 1911; they published most frequently in the journals Apollon and Giperborei. According to members or friends of the Guild, Acmeism stood for "beautiful clarity" (Kuzmin), "a nostalgia for world culture" (Mandelstam), and the concrete thingness of things, expressed in poetry of high technical artistry. As the brief biographies of the individual poets in this book's first main section below will suggest, the Acmeists too were a varied group. The Poets' Guild never actually came to a formal end, and some of its surviving members considered themselves Acmeists to the end of their lives.

\section{Brief Bibliography of Scholarly Works on Acmeism:}

Cavanagh, Clare. Lyric Poetry and Modern Politics: Poland, Russia and the West. New Haven: Yale University Press, 2009.

Doherty, Justin. The Acmeist Movement in Russian Poetry: Culture and the Word.

Oxford and New York: Oxford University Press, 1995.

Painter, Kirsten Blythe. Flint on a Bright Stone: A Revolution of Precision and Restraint in American, Russian and German Modernism. Stanford, CA: Stanford UP, 2006.

Strakhovsky, Leonid I. Craftsmen of the Word: Three Poets of Modern Russia:

Gumilyov, Akhmatova, Mandelstam. Westport, CT: Greenwood Press, $1949,1969$.

FUTURISM in Russia was perhaps the most ramified of the movements, involving various, often competing groups of poets and visual artists. The best-known branch of the movement is Cubo-Futurism, named for its members' attention to modern art of the time: some of them (David Burlyuk, Mayakovsky) began as visual artists. Vladimir Mayakovsky had done time in jail for smuggling a gun as a very young member of the Bolshevik Party and was therefore banned from most other institutions of higher education, so enrolled in the Moscow School of Painting, Sculpture and Architecture, where he met Burlyuk. This group included Viktor (Velimir) Khlebnikov and 
Alexei Kruchonykh, as well as several others. Khlebnikov in particular was almost a "language poet" before there was such a term; to the Western eye the work of the Cubo-Futurists may look postmodern before the era of postmodernism. The Ego-Futurists were headed by Igor Severyanin, pseudonym of Igor Lotaryov; other shorter-lived or more peripheral Futurist or Futurist-ish groups drew in the peasant poet Esenin and (more in character) Nikolai Aseev and Pasternak.

All the Futurists to some extent practiced the art of épatage; the Cubo-Futurists painted flowers on their faces, tucked a dead fish or a wooden spoon into their vest pockets in place of a handkerchief, or, in Mayakovsky's case, went about for some time in a yellow shirt his mother had made him, though he also appears in pre-Revolutionary photographs in elegant black evening wear with a top hat and a long cigarette holder-a devastating dandy. He and other Futurists toured, performed, and published outrageous collections and handmade volumes (printed on wallpaper and the like). ${ }^{2}$ The Cubo-Futurists especially came to be known for their manifestos, some of which are included in the second section of this volume; like much of their published poetry, these texts demonstrate a keen sense for publicity and certainty that there is no such thing as bad publicity. Not unlike their Western counterparts, some of them were eventually drawn into unsavory alliances with political authorities - though the two best-known, Khlebnikov and Mayakovsky, died before the highly compromising era of Stalinism began.

Their avant-garde outrageousness, their pugnacious sensibility, and their closeness to abstract and poster art make the Futurists-although loosely focused as a movement-one of the most exciting Silver Age schools. Like the Acmeists, they have been marvelously translated, and sophisticated scholars have been drawn to their work and its implications for literature and linguistics almost from the inception of the movement, when members of the Russian Formal School (Formalist critics) such as Viktor Shklovsky and Roman Jakobson admired and analyzed their writings.

2 An impressive online collection from an exhibit of these materials at the Metropolitan Museum of Modern Art can be found online at <http://www.moma.org/russian/>. 


\section{Brief Bibliography of Scholarly Works on Futurism:}

Barooshian, Vahan. Russian Cubo-Futurism, 1910-1930: A Study in AvantGardism. The Hague: Mouton, 1974.

Erlich, Victor. Modernism and Revolution: Russian Literature in Transition. Cambridge, MA and London: Harvard University Press, 1994.

Jakobson, Roman. “The Generation that Squandered Its Poets." Translated by

Dale E. Peterson. Yale French Studies, no. 39 (1967): 119-125.

Lawton, Anna and Herbert Eagle, eds. and trans. Russian Futurism through Its Manifestoes, 1912-1928. Ithaca: Cornell University Press, 1988.

Lifshits, Benedikt. The One and a Half-Eyed Archer. Translated, introduced, and annotated by John E. Bowlt. Newtonville, MA: Oriental Research Partners, 1977.

Markov, Vladimir. Russian Futurism: A History. London: MacGibbon \& Kees, 1969.

Proffer, Ellendea and Carl Proffer, eds. The Ardis Anthology of Russian Futurism. Ann Arbor: Ardis, 1980.

Although almost everyone had some connection with one or another of the schools - were friends with Futurists, attended "the Tower" in St. Petersburg or Bely's lectures in Moscow, or published a few poems in Apollon-many important poets were not affiliated with any of the three main movements. Given the legal reforms following 1905, it became possible to found and belong to a political party-or open a journal or newspaper-and participate in more open political debate. This change and the resulting political ferment could help explain both active, vocal participation in various schools at the time and the reluctance of some other poets to sign on, whether or not they respected the movement's poets and program. (Akhmatova's memoirs suggest that many more people were interested in politics than poetry at the time.) Taking account of movements helps a reader or scholar to keep straight some of what was going on, what the big debates or ideas were at certain moments, but in fact the arrangement was never as clear-cut as it might look now, in aesthetic and historical hindsight. See, for example, Parnok's article on the Acmeists: she was not herself a Symbolist, but she was friendly with a number of the Symbolists, a summer visitor of Voloshin, and very close to Adelaida Gertsyk and other less well-known poets whom we now view as Symbolists, 
not to mention her affair with the non-aligned Tsvetaeva, or her unfriendly relationship with the Acmeist Mandelstam. Barbara Heldt has pointed out that women were less likely to claim membership in the Silver Age schoolswhether because they felt less welcome there, or because they were less eager to join, or even because other obligations kept them from attending meetings or events where groups were formed and cultivated. Women who were members of this or that school were typically married to one of the men involved. ${ }^{3}$ Some of the "marginal" figures (Kuzmin, Parnok, Tsvetaeva - "marginal" in the sense of their positioning vis-à-vis the groups, not in their poetic importance) also explored alternative sexualities and interrogated the boundaries of gender. As the brief biographies for the poets suggest, however, gender was a popular

3 Here Heldt is worth quoting at length:

It must be understood that the nature of these groups was social as well as poetic. There was a felt kinship among members for however brief a time. The names the groups bear helped win publicity for their members during their lifetimes, as they help the subsequent student of Russian poetry begin to understand a past age. However, the real history of poetry must begin with the actual poetry written, not with labels like symbolist, acmeist, futurist or imagist. Critics have been saddled with these labels, but, interestingly, they have found women poets less classifiablewith the exception of poets whose husbands belonged to a group, as did those of Gippius, Akhmatova and [Elena] Guro.

A large anthology of twentieth-century poetry, Russkaia poeziia XX veka, published in Moscow in 1925 by I. S. Yezhov and E. I. Shamurin, groups poets according to schools, but nearly all the women poets included are in a category called 'poets not connected with definite groups.' These are: Lokhvitskaya, L'vova, Parnok, Shaginian, Stolitsa, Tsvetaeva, Pavlovich, Shkapskaya, Volchanetskaya, Butiagina, Odoevtseva, Inber, Polonskaya, Radlova, and Barkova, or sixteen of the thirty-five poets in that category. Of poets listed as belonging to groups, women comprise two out of nineteen symbolists (Gippius and Solov'eva), one out of ten acmeists (Akhmatova), one out of twelve futurists (Guro), and no peasant poets or proletarian poets (twelve and thirty-four males are listed, respectively). Whatever the reasons for the existence of groups, and however little they mean in terms of the actual poetry written, the independence of women is striking here. It may have been forced on them by exclusion: the tone of male assertiveness in the poetry of futurists like Mayakovsky or the quintessential imagist/peasant poet Esenin, as well as the flamboyantly male-oriented activities of their group, must have been a discouraging factor." Barbara Heldt, Terrible Perfection: Women and Russian Literature (Bloomington and Indianapolis: Indiana University Press, 1987), 116-117.

Though Heldt is citing from a publication at the very end of the Silver Age, the list of "non-aligned" women poets could be stimulus for further interesting reading. 
place for exploration - and this element, too, makes the Russian Silver Age fascinating for readers in our own time.

\section{The Big Topics}

The Silver Age poets, and many of their readers, engaged with a number of topics: sex, sin, religion, divinity (both Russian Orthodox and other), ritual, suicide, ecstasy, inspiration. Merezhkovsky described the idea of a sacralized materiality, or "holy flesh" (sviataia plot'), in a talk he gave at the ReligiousPhilosophical Meetings, and both Symbolists and others brooded over the relation of body or flesh and spirit. Female and male poets picked up discourse about gender roles (from authors such as Otto Weininger) ${ }^{4}$ and engaged with ideas of female and feminine creativity — noticeably unlike the Russian Romantics' appropriation of feminine discursive space while mocking actual women writers or preemptively placing them on pedestals during the Golden Age of Russian poetry.

Another striking element of the era was decadence, which accompanied a pervasive sense that culture was in decline-perhaps a well-deserved decline in the eyes of those upper-class poets who were wracked with guilt about the unfortunate position of peasants and workers in the Russian Empire. (See Gumilyov's grateful comment in the review in Section II on Klyuev's poetic offer, on behalf of Klyuev's fellow peasants, to welcome the upper classes into a new community.) The decadents (Bryusov, Sologub, sometimes Gippius) could toy with piquant depictions of sin, or they could raise fundamental questions of morality. Poets shared a widespread interest in the convergence of arts and the senses, exploring synaesthesia and attempting to construct new cultures, new worlds, while drawing on old cultures and traditions. The Futurists (as their name suggests) were taken with new technology, planes, fast cars, and urbanism, though these elements also show up in the work of other poets of the period. At the same time, the arche-Futurist Khlebnikov drew on archaic Slavic culture, its pagan gods and natural symbols, and on ancient Slavonic word roots in his poetic compositions. In their prose as well as their poetry, these poets imagined new religious communities and rituals; in this too they were not unlike West

4 Otto Weininger, Geschlecht und Charakter (Sex and Character), 1903, was translated into Russian before the First World War, though many educated Russians knew German and could read the influential book in the original. 
European and American Modernists. Even as the past seemed a vanishing source of authenticity and of closer connections between language and reality, now tragically lost, and as contemporary civilizations showed signs of decline, the poets built new edifices with thoughtful reference to the past. As mentioned before, the Silver Age poets attentively read the European Modernists and philosophers contemporary to them, along with their own idiosyncratic selections of earlier poets, such as François Villon (a favorite of Mandelstam) or Walt Whitman (translated by both Balmont and Kornei Chukovsky).

\section{Before and After: A Brief History}

After the Golden Age of Russian poetry in the early nineteenth century, according to the then-émigré scholar and critic D. S. Mirsky, the level of poetic craft declined terribly while the novel became the most prestigious literary genre. The last of the big Realists who began his writing life as a poet was Ivan Turgenev, a friend of Henry James and George Sand, born in 1818. Poetry was often denigrated in the era of Realism, coded as feminine (read: effeminate) and aristocratic (read: effete), especially by Russia's leftist positivist critics (Nikolai Chernyshevsky, Nikolai Dobrolyubov, Dmitri Pisarev). The most famous poets of the era after the Golden Age were mainly marginal figures: Lermontov was killed in a duel in 1841, at the age of twenty-six; Tyutchev spent most of his life abroad as a civil servant; Fet was admired by authors such as Leo Tolstoy, but his impact was delayed until the Silver Age, when he was seen as exemplarily musical and had many of his lyrics set as art songs. Pavlova spent the last decades of her life in emigration in Germany, and almost everything she wrote there was lost. The exception to this neglect of poetry was the civic poet and journalist Nikolai Nekrasov (1821-1878), best known now for his long poems with sometimes tendentious subject matter, though some of his love poetry resonates with that of Blok and other Symbolists. Russian poets who immediately preceded the Silver Age have not fared well with later critics: Semyon Nadson (1862-1887) in particular was scorned by Silver Age poets for his pathos-ridden verse and poor technique, as well perhaps as for his popularity with less sophisticated readers. It may be typical for a new poetic era to begin by denigrating everything it objects to in the preceding one and (as it were) jumping over the heads of the "parents" to the "grandparents," the poets of the Golden Age. 
The Silver Age began as the great Realist era was coming to an end: Fyodor Dostoevsky died in 1881, Ivan Turgenev in 1883, Nadezhda Khvoshchinskaya in 1889, Nikolai Leskov in 1895, and although Leo Tolstoy lived until 1910 he was now active as a moral teacher and thinker, having rejected his own fiction decades before. The early Symbolists gained energy partly from discovering and rediscovering poets of the nineteenth century who had not been properly appreciated: Vladimir Benediktov (1803-1873), Karolina Pavlova, and Konstantin Fofanov (1862-1911). The new school of poets was seeking elevated craft (Pavlova), verbal music and exotic language (Benediktov, Fofanov, and also Mirra Lokhvitskaya, who belongs here in the Silver Age but died young of tuberculosis, in 1905). At the same time, authors of the Silver Age by no means shirked the writer's authority and even duty to comment on social issues, which the poets had inherited from previous decades. They were eager to write for the "thick" journals of the late 1800s and the early 1900s, and these journals were full of articles by Gippius, Blok, and other Symbolists. The achievements of Russian Realism continued to some extent in shorter prose forms, by brilliant authors such as Anton Chekhov, Maxim Gorky, and Ivan Bunin. Leo Tolstoy remained a real and continuing reference point for Silver Age writers thinking about civic engagement-the pages of the journal Mir Iskusstva (World of Art) are full of references to him. This legacy endured in the Silver Age for years after his death. Scholars have also agreed with Mandelstam's comment that Russian novels of the nineteenth century lived on as the psychological underpinnings of Akhmatova's understated early poems.

Almost all the poets of the Silver Age welcomed the tsar's abdication in early 1917, but their culture was fatally ruptured by the October 1917 Revolution: some of our poets died much too young (Gumilyov was shot in 1921; Blok and Khlebnikov died in 1921 and 1922, both of a combination of starvation and illness); some emigrated and continued to work in smaller communities and increasing poverty, often growing more conservative in their writing (though Khodasevich, Severyanin, Tsvetaeva and others did their best work in emigration, after 1917); some remained in Russia, now the Soviet Union, and adapted in one way or another. For a few years the borders remained open, and many poets traveled back and forth from the USSR to Western Europe or published both in Berlin and in Moscow. Some were eventually unable to adapt as the new situation began to harden: Esenin and Mayakovsky committed 
suicide, and Mandelstam (who had tried in some ways to accommodate himself to the new situation) was arrested twice and died on his way to a prison camp in 1938. Some of Klyuev's major works were preserved only in a secret police archive, after his final arrest. Pasternak survived and even enjoyed some fame under Stalin, but his lover Olga Ivinskaya was arrested and sent to a camp to keep him in line, and the end of his life was darkened by scandal; after Doctor Zhivago was published abroad, he was awarded the Nobel Prize for Literature but not allowed to travel to receive it. Kuzmin and Parnok died sooner than they should have, of malnourishment and ill health. Women were often taken less seriously by the Soviet regime and thus were more likely to survive, though that imposed a new set of obligations: to fall silent as a poet, like Shkapskaya, in order to protect her family, or to represent the Silver Age itself in a later era, like Akhmatova. Tsvetaeva, whose life story is unusually full of incident, returned to the USSR in 1939, not long before the Second World War began, and committed suicide in 1941 under circumstances that are still murky but seem to implicate the literary establishment and/or the secret police. A new set of literary groups formed in the early Soviet period, some of them fascinating and very much worth reading (such as the Leningrad absurdists of OBERIU), but independent groups were quickly smacked down by the newly formed All-Soviet Writers' Union. (Many authors at first saw the Union as a good development, since some early Soviet literary groupings had been aggressively unpleasant to anyone who disagreed with their programs.) A few of our poets outlived Stalin: Pasternak died in 1960, Aseev in 1963, Akhmatova in 1966, and Kruchonykh in 1968 - and we could argue that their work after the 1920s belongs to and reflects a different era and poetic moment, even when it harkens back to the Silver Age: Ahmatova's Poem without a Hero can serve as a primer for understanding this period. In hindsight, the many personal losses lend a tragic tinge to the Silver Age, even for the poets who did survive beyond it. A reader cannot help thinking: what would have developed out of this amazing ferment, if war and revolution hadn't intervened?

Silver Age poetry enjoyed an odd afterlife in Russian literature: the Soviet period imposed a sort of cultural deep freeze that kept many of its voices out of public discourse but thereby preserved and even increased its importance, especially for readers who trusted poetry more than political parties. Meanwhile, the conformist literary establishment rolled back some Silver Age poetic 
innovations and kept much of the best poetry under wraps (especially the poets who were under thirty in 1917, whose development was both intensified and made more difficult by the rapidly changing conditions of their lives). A new flare-up of great Russian poetry in the 1960s — a cultural marker of the Thaw period that was never quite squashed when Leonid Brezhnev came to preside over the so-called era of Stagnation-in many ways advanced the achievements and importance of the Silver Age. Some poetry of the Thaw grew into an avant-garde underground that was not cut off by arrests and prison sentences, though it was available only in samizdat, unofficial self-publication, and still carried certain risks. Because the development of Russian poetry in the Soviet Union was artificially slowed, the Silver Age's poetry felt truly vital and contemporary until the 1990s. It is no accident that one of the most prominent late-Soviet poets, Joseph Brodsky (1940-1996), carefully read Akhmatova (whom he knew personally), Mandelstam, and Tsvetaeva, composing insightful essays about their writing and lives. Poets who had suffered and died acquired a moral authority that also heightened their aesthetic importance (see Bella Akhmadulina [1937-2010] writing about Mandelstam or Tsvetaeva). Even now, the great Silver Age poets are loved by Russian readers around the world.

Recent Russian poetry is moving in a variety of new directions, and the status of the Russian poet has changed to become more like that of Western analogues: the loss of state sponsorship has meant both freedom (from censorship and Socialist Realism) and exposure to new and often unhelpful forces in the literary marketplace. "Being a famous poet isn't the same as being famous," as one (famous) American poet declared. Nevertheless, today's Russian poets know their Silver Age predecessors excellently, and some (Olga Sedakova, Vladimir Gandelsman, Maria Stepanova, Polina Barskova, or the late Elena Shvarts) consciously and overtly draw on and refer to the Silver Age tradition in their work and their thinking.

\section{The Russian Silver Age in the West}

The poets of the Silver Age had the benefit of being introduced to Anglophone readers by D. S. Mirsky in his survey of modern Russian literature, published in 1925, around what we might call the end of the Silver Age. By 1925, Akhmatova was no longer able to publish much poetry; Mandelstam had entered a five-year hiatus in his writing; Blok and Khlebnikov were dead; Shkapskaya 
was soon to stop writing poetry (at least, any that has survived). For many reasons, the story of the Russian Silver Age was only partly told for a time in the West: émigré poets were often taken less seriously, seen as a lesser cultural phenomenon or as representatives of an obsolete social class, while poets who remained in the USSR were eventually enclosed by the Iron Curtain. For a time Anglophone publishers favored Silver Age prose writers-Merezhkovsky's novels, for example, were translated early and fairly often retranslated, as was Fyodor Sologub's Petty Demon. After Stalin's death, during and after the Thaw, Western readers made a series of discoveries that each quickly reverberated in scholarship: Pasternak became famous when he was denied access to the Nobel Prize; Akhmatova, when her poetry began to appear in more complete Soviet editions and she was invited to be honored in Britain and Italy; Mandelstam, when his widow managed to get his manuscripts out of the country for publication; Tsvetaeva, when her daughter had some of her poetry published and then more copiously republished in the USSR. The Futurists, especially Khlebnikov and Mayakovsky, have always appealed to both scholars and readers with a taste for the avant-garde. Because Soviet censorship made it difficult for scholars to access the complete collections of some Silver Age poets, and potentially dangerous for a scholar to probe too deeply in a poet's work and career, Western scholarship on the Silver Age was as likely to be cutting-edge as work published in the USSR — and the presence of many important Russian or former Soviet scholars in emigration also helped to establish high-quality traditions of interpretation. Scholars such as Italian critic Renato Poggioli helped give a sophisticated introduction of the poets and their importance to readers in the West. Not only are the most famous of the Russian Modernist poets now available in many very effective translations into English, they have also significantly influenced and impacted poets in other traditions. (Looking at a poem by Irish poet Nuala Ni Dhomhnaill, dedicated to Tsvetaeva, one need not posit a very long series of connections: Joseph Brodsky was a good friend of Seamus Heaney.)

For those who would like to read and explore more, the select bibliographies below include translations of our poets (sometimes, only part of the cited work is from the Silver Age) and scholarly books on Silver Age topics larger than just one writer or poetic school. Some of these books have helped to shape our own approach to the period, and the most recent books on the list (such as 
those by Colleen McQuillen and Sara Pankenier Weld) show that the poetry and culture of the Silver Age continue to attract and fascinate some of the best scholars working on Russian literature.

\section{SELECTED BIBLIOGRAPHY: THE RUSSIAN SILVER AGE}

\section{Translations}

Chandler, Robert, Irina Mashinski, and Boris Dralyuk, eds. The Penguin Book of Russian Poetry. London: Penguin Classics, 2015.

Glad, John, and Daniel Weissbort, eds. Russian Poetry: The Modern Period. Iowa City, IA: University of Iowa Press, 1974.

Kazakova, Rimma, ed. The Tender Muse. Moscow: Progress Publishers, 1976.

Kelly, Catriona, ed. An Anthology of Russian Women's Writing, 1777-1992. Translated by Catriona Kelly, Sibelan Forrester, Diana Greene, Elizabeth Neatrour, Brian Thomas Oles, Marian Schwartz, and Mary Zirin. Oxford and London: Oxford University Press, 1994.

Mager, Don, ed. and trans. Us Four Plus Four: Eight Russian Poets Conversing. New Orleans, LA: UNO Press, 2009.

Markov, Vladimir, and Merrill Sparks, eds. Modern Russian Poetry. Indianapolis and New York: Bobbs-Merrill Company, Inc., 1967.

Muchnik, Slava, ed. Salt Crystals on an Axe/Kaк cosь на monope. TwentiethCentury Russian Poetry in Congruent Translation. A Bilingual MiniAnthology. Translated by Alex Shafarenko. Godalming, Surrey, UK: Ancient Purple, 2009.

Nabokov, Vladimir, trans. Verses and Versions: Three Centuries of Russian Poetry. Edited by Brian Boyd and Stanislav Shvabrin. Orlando: Harcourt, Inc., 2008.

Natchez, Meryl, trans., with Boris Wolfson and Polina Barskova. Poems from the Stray Dog Café: Akhmatova, Mandelstam, Gumilev. Hit \& Run Press, 2013. Obolensky, Dimitri, ed. The Heritage of Russian Verse. Bloomington \& Indianapolis: Indiana University Press, 1976.

Pachmuss, Temira. Women Writers in Russian Modernism: An Anthology. Urbana: University of Illinois Press, 1978.

Peterson, Ronald E., ed. and trans. The Russian Symbolists. Ann Arbor, MI: Ardis Publishers, 1986. 
Proffer, Carl, and Ellendea Proffer, eds. The Silver Age of Russian Culture. Ann Arbor, MI: Ardis Publishers, 1975.

Schmidt, Paul, trans. The Stray Dog Cabaret: A Book of Russian Poems. New York: NYRB Classics, 2006.

Tomei, Christine, ed. Russian Women Writers. New York: Garland, 1998.

West, Thomas G., ed. Symbolism: An Anthology. London \& New York: Methuen, 1980.

Yarmolinsky, Avrahm, ed. Two Centuries of Russian Verse: An Anthology, from Lomonosov to Voznesensky. Translated by Babette Deutsch. New York: Random House, 1966.

Yevtushenko, Yevgeny, ed. Translated by Albert G. Todd and Max Hayward (with Daniel Weissbort). 20th Century Russian Poetry: Silver and Steel. New York: Doubleday, 1993.

\section{CULTURE AND SCHOLARSHIP}

Bowlt, John E. Moscow \& St. Petersburg, 1900-1920: Art, Life, \& Culture of the Russian Silver Age. New York: Vendome Press, 2008.

Crone, Anna Lisa. Eros and Creativity in Russian Religious Revival: The Philosophers and the Freudians. Leiden and Boston: Brill, 2010.

Gasparov, Boris, Robert Hughes, and Irina Paperno, eds. Cultural Mythologies of Russian Modernism: From the Golden Age to the Silver Age. Berkeley, CA: University of California Press, 1992.

Greenfield, Douglas, ed. Alter Icons: The Russian Icon and Modernity. University Park, PA: Pennsylvania State University Press, 2010.

Grillaert, Nel. What the God-Seekers Found in Nietzsche: The Reception of Nietzsche's Übermensch by the Philosophers of the Russian Religious Renaissance. Amsterdam and New York: Rodopi, 2008.

Hingley, Ronald. Nightingale Fever: Russian Poets in Revolution. New York: Knopf, 1981.

Kelly, Catriona, and Stephen Lowell, eds. Russian Literature, Modernism, and the Visual Arts. Cambridge, UK: Cambridge University Press, 2000.

Loewen, Donald. The Most Dangerous Art: Poetry, Politics and Autobiography After the Russian Revolution. Lanham: Lexington Books, 2008.

Matich, Olga. Erotic Utopia: The Decadent Imagination in Russia's Fin-de-Siècle. Madison, WI: University of Wisconsin Press, 2005. 
McQuilllen, Colleen. The Modernist Masquerade: Stylizing Life, Literature, and Costumes in Russia. Madison, WI: The University of Wisconsin Press, 2013.

Mirsky, D. S. Modern Russian Literature. London: Oxford University Press, 1925.

Paperno, Irina, and Joan Delaney Grossman, eds. Creating Life: The Aesthetic Utopia of Russian Modernism. Stanford, CA: Stanford University Press, 1984.

Rylkova, Galina. The Architecture of Anxiety: The Russian Silver Age and Its Legacy. Pittsburgh: University of Pittsburgh Press, 2007.

Weld, Sara Pankenier. Voiceless Vanguard: The Infantilist Aesthetic of the Russian Avant-Garde. Evanston, IL: Northwestern University Press, 2014. 